\title{
Comparative Study of Irrigation Scheduling for Mustard Crop using Climatological Method and CROPWAT Model
}

\author{
Neel Praveen Kullu*, Mintu Job, D. K. Rusia, Pramod Rai and Alpna Dubey \\ Department of Agricultural Engineering, Birsa Agricultural University, \\ Ranchi, Jharkhand, India \\ *Corresponding author
}

\section{A B S T R A C T}

\section{Keywords}

Climatological, CROPWAT, Water use efficiency

\section{Article Info}

Accepted:

12 November 2019

Available Online:

10 December 2019
The knowledge of crop water requirement and Irrigation scheduling is an important practical consideration for designing and managing an irrigation system. A field study was conducted to find out the irrigation scheduling of Mustard crop by Climatological method and its comparison with CROPWAT model from rainwater harvested through plastic lined pond during the year 2018-19 at PFDCPET farm of the BAU Ranchi Jharkhand. Through pan evaporation method, total Crop water requirement was estimated $323.23 \mathrm{~mm}$ out of which $300 \mathrm{~mm}$ water was given through irrigation. Irrigation was scheduled through climatological method with IW/CPE ratio 0.9 and depth of irrigation kept at $6 \mathrm{~cm}$ through five irrigations at $22,42,63,82$, and 93 DAS. Total yield obtained through climatological method was $922 \mathrm{~kg} / \mathrm{ha}$. The irrigation scheduling and net irrigation requirement were compared with CROPWAT model, based on climatic data, crop data and soil data of the region. Total gross irrigation requirement through the CROPWAT model was $252.2 \mathrm{~mm}$ with total four irrigations at $36,52,68,80$ DAS and yield was $1162 \mathrm{~kg} / \mathrm{ha}$. So, for better water use efficiency CROPWAT model can be used in the region.

\section{Introduction}

Mustard is an important oilseed crop of India grown in Rabi season. India is the fourthlargest contributor of oilseeds and mustard contributes about $28.6 \%$ in total oilseeds production (Agriculture statistics, department of agriculture and farmer welfare, Government of India 2018). Due to scarcity and unavailability of irrigation water, Production of Mustard is lesser than average production of the country. The average yield of $646 \mathrm{~kg} / \mathrm{ha}$ of Jharkhand as against the country's average yield $1156 \mathrm{~kg} / \mathrm{ha}$ (Agriculture statistics, department of agriculture and farmer welfare Government of India, 2018). The knowledge of crop water requirement is an important practical 
consideration for designing and managing an irrigation system. Optimum crop yield is not possible without the application of a timely and right amount of irrigation water. Since rainfall during this period is inadequate and uncertain, mustard requires supplemental irrigation for its proper growth and development, otherwise, the crop is likely to suffer from water stress and reduce ultimately the yield. To determine the irrigation requirement at a particular crop growth stage, it is necessary to know the crop co-efficient values at different growth stages.

Crop co-efficient or Kc value is the empirical ratio of actual evapotranspiration $\left(\mathrm{ET}_{\mathrm{c}}\right)$ to the reference crop evapotranspiration $\left(\mathrm{ET}_{\mathrm{o}}\right)$. The crop coefficient values are necessary for different crops grown under different climatic conditions. These values are commonly used in the place where the local data are not available. In the case where these data are not available irrigation can be supplied to the crop based on the critical stages which are governed by the irrigation frequency or the number of irrigation given to a crop during its lifecycle. Estimation of crop water requirement and irrigation scheduling requires careful consideration for any irrigation project.

There are various computer-based models available for estimation of crop water requirement and irrigation scheduling like DSSAT, AQUACROP, Cropflex, watertight, CROPWAT, NDSU and many more. Out of which it CROPWAT is found very userfriendly and requires easily available data than other models. CROPWAT is a Window-based computer program for the calculation of crop water requirements and irrigation requirements based on soil, climate and crop data. Also, the program allows the development of irrigation schedules for different management conditions and the calculation of scheme water supply for varying crop patterns

\section{Materials and Methods}

\section{Description of the study area}

The study is located at PFDC-PET farm, Birsa Agricultural University, Kanke, Ranchi, Jharkhand. The geographical location of Kanke, Ranchi is $23^{\circ} 20^{\prime}$ 'N latitude and $85^{\circ} 18^{\prime} \mathrm{E}$ longitude at an elevation of $651 \mathrm{~m}$ above mean sea level. The study area falls under Ranchi region of Jharkhand Agro Climatic zone VII of the country known as Eastern Plateau and Hill region. Climatic character is subtropical humid and soil of the study area is loamy in texture with bulk density $1.57 \mathrm{gm} / \mathrm{c} . \mathrm{c}$ The average annual rainfall of the station is about $1380 \mathrm{~mm}$, out of which, 90 percent is received in monsoon season (June-Sept), Whereas $4.7 \%$ and $5.3 \%$ are contributed by post monsoon(Oct-January) and Pre Monsoon season(February- May), Respectively. Month of August contributed maximum $37 \%$ to total rainfall followed by July which is $31 \%$

\section{Irrigation scheduling using CROPWAT model}

\section{Calculation of reference Evapo- transpiration (ETo) using CROWAT}

ETo was calculated according to PenmanMonteith method using CROPWAT 8.0 model.The Penman-Monteith equation (FAO, 1998)integrated in the CROPWAT program is expressed by equation (1) as follows;

$E T_{0}=\frac{0.408 \Delta\left(R_{n}-G^{\prime}+\gamma \frac{900}{T+273} u_{2}\left(e_{s}-e_{a}\right)\right.}{\Delta+\gamma\left(1+0.34 u_{2}\right)}$

Where, $\mathrm{ET}_{\mathrm{o}=}$ reference evapotranspiration $\left[\mathrm{mm}\right.$ day $\left.^{-1}\right], \mathrm{R}_{\mathrm{n}=}$ net radiation at the crop surface $\left[\mathrm{MJ} \mathrm{m}^{-2} \mathrm{day}^{-1}\right], \mathrm{G}=$ soil heat flux density $\left[\mathrm{MJ} \mathrm{m} \mathrm{m}^{-2}\right.$ day $\left.^{-1}\right], \mathrm{T}=$ mean daily air temperature at $2 \mathrm{~m}$ height $\left[{ }^{\circ} \mathrm{C}\right], \mathrm{u}_{2}=$ wind speed 
at $2 \mathrm{~m}$ height $\left[\mathrm{m} \mathrm{s}^{-1}\right], \mathrm{e}_{\mathrm{s}=}$ saturation vapour pressure $[\mathrm{kPa}], \mathrm{e}_{\mathrm{a}=}$ actual vapour pressure $[\mathrm{kPa}], \mathrm{e}_{\mathrm{s}}-\mathrm{e}_{\mathrm{a}}$ saturation vapour pressure deficit $[\mathrm{kPa}], \mathrm{D}=$ slope vapour pressure curve $[\mathrm{kPa} \mathrm{C}$ $\left.{ }^{1}\right], \mathrm{g}=$ psychrometric constant $\left[\mathrm{kPa}^{\circ} \mathrm{C}^{-1}\right]$.

\section{Determination of crop evapotranspiration}

Crop evapotranspiration was obtained by:

$\mathrm{ET}_{\mathrm{c}}=\mathrm{K}_{\mathrm{c}} \cdot \mathrm{ET}_{\mathrm{o}} \ldots($ eq. 3$)$

Where,

$\mathrm{ET}_{\mathrm{c}}=$ crop evapotranspiration $(\mathrm{mm} /$ day $)$

$\mathrm{K}_{\mathrm{c}}=$ crop coefficient

$\mathrm{ET}_{\mathrm{o}}=$ Reference crop evapotranspiration

\section{Study of rainfall data during crop period}

Monthly rain data of 2018-2019 was analyzed using USDA soil conservation formula to estimate effective rainfall.

Eff. rain method: USDA Soil Conservation Service formula:

Peff $=$ Pmon $*(125-0.2 *$ Pmon $) / 125$ forPmon $<=250 \mathrm{~mm} .$. (eq. 4 )

Peff $=125+0.1 *$ Pmon for Pmon> 250 mm...(eq. 5)

Where, Peffective $=$ effective monthly rainfall $(\mathrm{mm})$,

Pmon $=$ total monthly rainfall $(\mathrm{mm})$

\section{Crop data}

Mustard was grown in rabi season. Mustard growing period was divided as: (i) initial stage (25 days) (ii) crop development stage (35 days) (iii) mid stage (45 days) and (iv) late stage (flowering to maturity, 30 days) In this study, irrigation scheduling was done for Shivani variety of Indian mustard.

Crop was sown on $24^{\text {th }}$ October 2018 and harvested on $6^{\text {th }}$ march $2019 . K_{c}$ values were taken, $0.39,1.0,1.31$ and 0.46 for different growth stages.

\section{Soil data}

Bulk density of soil was $1.5 \mathrm{~g} \mathrm{~cm}^{-3}$ with maximum infiltration rate $40 \mathrm{~mm} /$ day. Moisture content at field capacity and wilting point were $26.8 \%$ and $12.9 \%$, respectively.

\section{Estimation of irrigation water requirement and time of application}

Crop irrigation water requirement (CWR) refers to the amount of water that needs to be supplied, while crop evapotranspiration $\left(\mathrm{ET}_{\mathrm{c}}\right)$ refers to the amount of water that is lost through evapotranspiration (Allen et al., 1998). CWR (mm) was determined according to FAO (2005) as;

$\mathrm{CWRi}=\sum_{t=0}^{T} K_{c i}$. Etc - Peff.. ...(eq. 6)

Where, Kci is the crop coefficient of the given crop $\mathrm{i}$ during the growth stage $\mathrm{t}$ and $\mathrm{T}$ is the final growth stage. The crop evapotranspiration $\mathrm{ET}_{\mathrm{c}}=\mathrm{K}_{\mathrm{c}} \times \mathrm{ET}_{\mathrm{o}}$ where $\mathrm{K}_{\mathrm{c}}$ is crop coefficient and $\mathrm{ET}_{\mathrm{o}}=$ reference crop evapotranspiration ( $\mathrm{mm} /$ day)

Irrigation scheduling using climatological method (IW/CPE)

\begin{tabular}{lccc} 
Calculation & of & \multicolumn{2}{r}{ reference } \\
$\begin{array}{l}\text { Evapotranspiration } \\
\text { evaporation method }\end{array}$ & (ETo) & using & Pan \\
& & &
\end{tabular}

Evaporation pans provide a measurement of the integrated effect of radiation, wind, temperature and humidity on evaporation from a specific open water surface. 
Reference crop evapotranspiration (ETo) was obtained from: $\mathrm{ET}_{\mathrm{o}}=\mathrm{K}_{\mathrm{p}} \cdot \mathrm{X} \mathrm{E}_{\mathrm{pan}} \ldots \ldots$...(eq. 7)

Where, $: \mathrm{E}_{\mathrm{pan}}=$ pan evaporation in $\mathrm{mm} /$ day and represents the mean daily value of the period considered

$\mathrm{K}_{\mathrm{p}}=$ pan coefficient (varies according to the wind velocity, relative humidity and sunshine hours)

\section{Irrigation scheduling using climatological method (IW/CPE)}

The irrigation schedule as per climatological approach was prepared based on study of previous 20 years daily pan evaporation data. The data included daily cumulative pan evaporation data. Pirharet al., (1974) suggested relatively simple IW/CPE approach for scheduling crop irrigation. Evaporation mainly depends upon climate. The amount of water lost by evapotranspiration was estimated from climatological data and when ET reaches a threshold level, irrigation is scheduled. The amount of irrigation given is either equal to ET or fraction of ET.A known amount of irrigation water (IW) that is $6 \mathrm{~cm}$ was applied when cumulative pan evaporation (CPE) reaches a predetermined level. Irrigation was applied at 0.9 ratios with $6 \mathrm{~cm}$ of irrigation water and yield obtained through climatological method irrigation scheduling was $922 \mathrm{~kg} / \mathrm{ha}$.

\section{Results and Discussion}

Crop water requirement and irrigation scheduling using CROPWAT

The model estimated mean annual crop evapotranspiration of Mustard crop, which was $252.2 \mathrm{~mm}$ for Kanke, Ranchi Jharkhand. The observed ETc values were higher (more than average) during December and January and lower during October and February (Table 1). The highest monthly ETc $(34 \mathrm{~mm})$ was found in third decade of December and the lowest $(4 \mathrm{~mm})$ in first decade of February.

In December and January, during mid-stage of crop and due to high crop coefficient values and low relative humidity resulted in increased crop evapotranspiration. After processing climatic data soil data and Crop data in CROPWAT 8.0 software, it was found that total crop water requirement was $221 \mathrm{~mm}$ and total gross irrigation was $252.2 \mathrm{~mm}$.

After 36 days from the sowing of mustard, the first irrigation of $58.1 \mathrm{~mm}$ should be given to protect the crop from water stress condition. Further irrigations should be given after 52 , 68, and 80 days after sowing with 66.2, 65.9, 65.9, and $63.6 \mathrm{~mm}$ respectively. After analyzing soil data and type of irrigation, field efficiency was taken $70 \%$ by CROPWAT model during each irrigation supplied flooding and grain yield obtained through CROPWAT irrigation scheduling was $1162 \mathrm{~kg} / \mathrm{ha}$.

Crop water requirement and irrigation scheduling of mustard crop using the climatological method

Through pan evaporation method crop water requirement for mustard crop was found $323.20 \mathrm{~mm}$ out which $300 \mathrm{~mm}$ water was given through irrigation. Twenty years of weekly pan evaporation data, rainfall, and initial soil moisture condition was analyzed. Irrigation was scheduled at IW/CPE ratio 0.9 with depth of irrigation $6 \mathrm{~cm}$ (Table 2).

IW/CPE ratio 0.9 was taken to schedule irrigation because it was recommended for loamy soil and humid subtropical climate. (By Singh and Pannu 1998, and Ideal IW/CPE ratio 0.8-1.05 by FAO 56 for the mustard crop)Total five irrigations with total irrigation water $300 \mathrm{~mm}$ were given and irrigation efficiency was assumed 60\% (by FAO 56) (Fig. 1 and 2). 
Table.1 Crop water requirement and irrigation requirement for mustard crop (CROPWAT model)

\begin{tabular}{|c|c|c|c|c|c|c|c|}
\hline Month & $\begin{array}{c}\text { Dec } \\
\text { ade }\end{array}$ & Stage & $\begin{array}{c}\text { Kc } \\
\text { Coeff. }\end{array}$ & $\begin{array}{c}\text { ETc } \\
\mathbf{m m} \\
\text { /day }\end{array}$ & $\begin{array}{c}\text { ETc } \\
\mathbf{M m} / \\
\mathbf{d e c}\end{array}$ & $\begin{array}{c}\text { eff.rain } \\
\mathbf{m m} / \mathbf{d e c}\end{array}$ & $\begin{array}{c}\text { Irr. Req } \\
\mathbf{M m} / \mathbf{d e c}\end{array}$ \\
\hline Oct & 3 & Init. & 0.39 & 1.25 & 12.5 & 0.0 & 12.5 \\
\hline Nov & 1 & Deve & 0.40 & 1.21 & 12.1 & 0.0 & 12.1 \\
\hline Nov & 2 & Deve & 0.63 & 1.77 & 17.7 & 0.0 & 17.7 \\
\hline Nov & 3 & Deve & 0.95 & 2.52 & 25.2 & 0.0 & 25.2 \\
\hline Dec & 1 & Mid & 1.24 & 3.13 & 31.3 & 0.0 & 31.3 \\
\hline Dec & 2 & Mid & 1.31 & 3.09 & 30.9 & 0.0 & 30.9 \\
\hline Dec & 3 & Mid & 1.31 & 3.09 & 34.0 & 0.0 & 34.0 \\
\hline Jan & 1 & Mid & 1.31 & 3.10 & 31.0 & 0.0 & 31.0 \\
\hline Jan & 2 & Late & 1.11 & 2.61 & 26.1 & 0.0 & 26.1 \\
\hline Jan & 3 & Late & 0.72 & 1.88 & 20.7 & 0.0 & 20.7 \\
\hline Feb & 1 & Late & 0.46 & 1.32 & 4.0 & 0.0 & 4.0 \\
\hline Total cumulative & & & & & 221. & & $252.2 \mathrm{~mm}$ \\
\hline & & & & & mm & & $($ at $70 \%)$ \\
\hline
\end{tabular}

Table. 2 Crop water requirement of mustard crop using pan evaporation method

\begin{tabular}{|c|c|c|c|c|c|c|c|}
\hline Month & $\begin{array}{c}\text { Dec } \\
\text { ade }\end{array}$ & Stage & Kc & $\begin{array}{c}\text { ETc } \\
\mathbf{m m} / \mathbf{d a y}\end{array}$ & $\begin{array}{c}\text { ETc } \\
\mathbf{m m} / \\
\mathbf{d e c}\end{array}$ & $\begin{array}{c}\text { Eff. } \\
\text { Rain } \\
\mathbf{m m} / \mathbf{d e c}\end{array}$ & $\begin{array}{c}\text { CWR } \\
\mathbf{m m} / \mathbf{d e c}\end{array}$ \\
\hline Oct & 3 & Initial & 0.39 & 1.55 & 15.55 & 0.0 & 33.0 \\
\hline Nov & 1 & Development & 0.40 & 1.60 & 16.0 & 0.0 & 26.9 \\
\hline Nov & 2 & Development & 0.62 & 1.96 & 19.6 & 0.0 & 33.2 \\
\hline Nov & 3 & Development & 0.93 & 2.49 & 24.9 & 0.0 & 39.2 \\
\hline Dec & 1 & Mid & 1.22 & 3.08 & 30.8 & 0.0 & 40.4 \\
\hline Dec & 2 & Mid & 1.29 & 3.04 & 30.4 & 0.0 & 36.2 \\
\hline Dec & 3 & Mid & 1.29 & 3.04 & 33.5 & 0.0 & 31.3 \\
\hline Jan & 1 & Mid & 1.29 & 2.57 & 25.7 & 0.0 & 17.5 \\
\hline Jan & 2 & Late & 1.09 & 2.53 & 25.9 & 0.0 & 24.5 \\
\hline Jan & 3 & Late & 0.71 & 1.86 & 20.5 & 0.0 & 17.5 \\
\hline Feb & 1 & Late & 0.46 & 1.32 & 4.0 & 0.0 & 0.0 \\
\hline
\end{tabular}


Table.3 Comparison CROPWAT model and climatological method

\begin{tabular}{|c|c|c|}
\hline Particular & $\begin{array}{c}\text { CROPWAT } \\
\text { MODEL }\end{array}$ & $\begin{array}{c}\text { Climatological } \\
\text { method }\end{array}$ \\
\hline $\begin{array}{c}\text { Net irrigation } \\
\text { requirement }\end{array}$ & $221 \mathrm{~mm}$ & $303.6 \mathrm{~mm}$ \\
\hline $\begin{array}{c}\text { Gross } \\
\text { irrigation } \\
\text { requirement }\end{array}$ & $252.2 \mathrm{~mm}$ & $323.30 \mathrm{~mm}$ \\
\hline $\begin{array}{c}\text { Total number } \\
\text { of irrigation }\end{array}$ & 4 & 5 \\
\hline $\begin{array}{c}\text { Irrigation } \\
\text { days (DAS) }\end{array}$ & $36,52,68,80$ & $22,42,63,81,93$ \\
\hline Yield(kg/ha) & $1162 \mathrm{~kg} / \mathrm{ha}$ & $922 \mathrm{~kg} / \mathrm{ha}$ \\
\hline
\end{tabular}

Fig.1 Irrigation scheduling using CROPWAT model

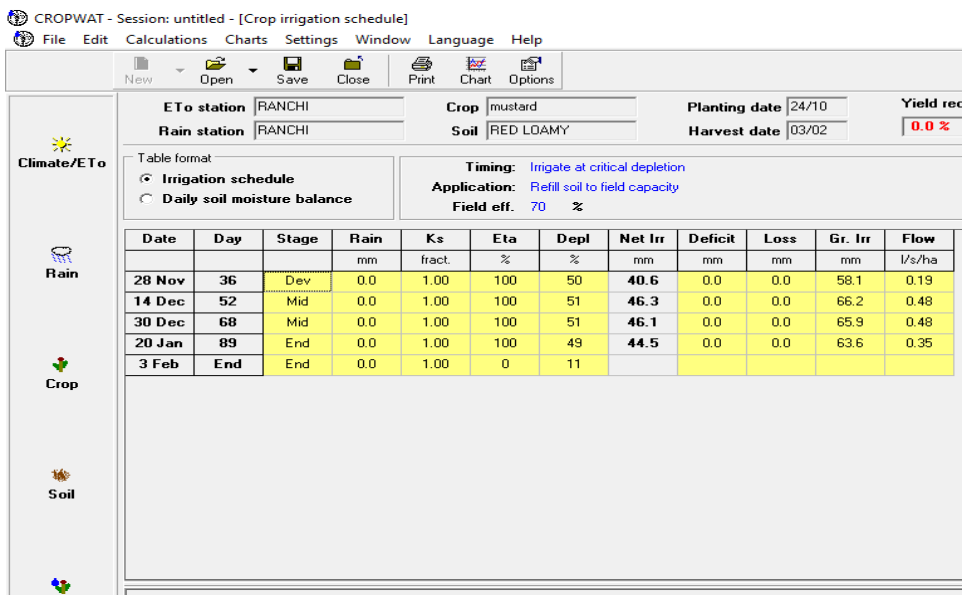

Fig.2 Irrigation scheduling using climatological method

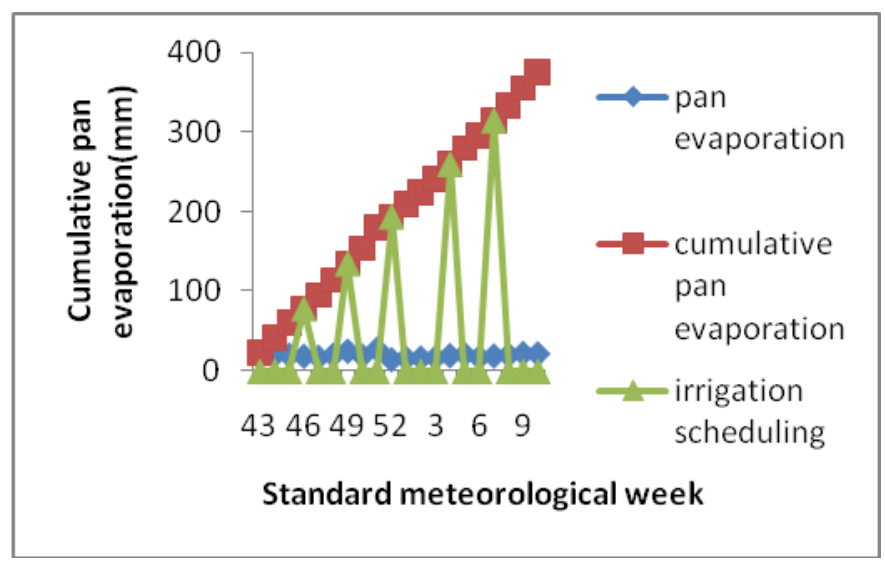


Fig.3 Comparison of crop water requirement of mustard using CROPWAT and climatological method

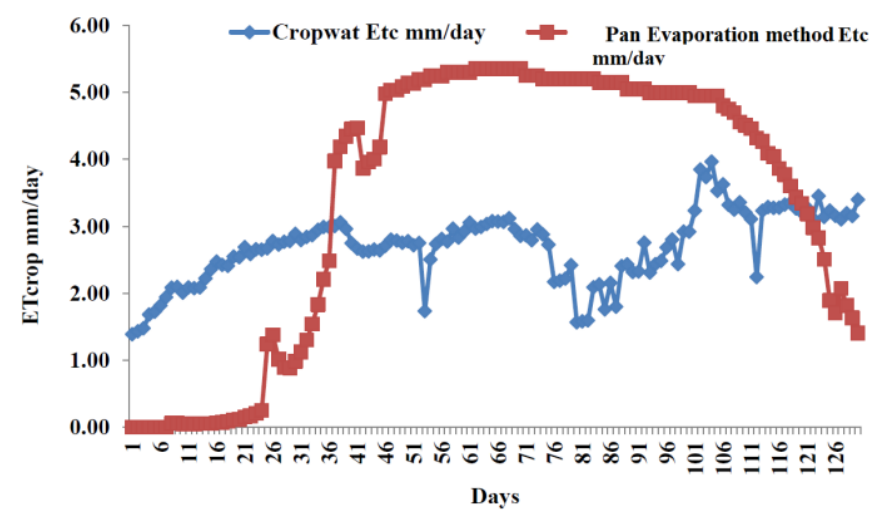

According to daily cumulative pan evaporation data $1^{\text {st }}, 2^{\text {nd }}, 3^{\text {rd }}, 4^{\text {th }}$ and $5^{\text {th }}$ irrigation was scheduled at every $62 \mathrm{~mm}$ cumulative pan evaporation value. $1^{\text {st }}$ irrigation was scheduled at 22 days after sowing and after this subsequent irrigation was given at 42, 63, 81 and 93 days after sowing with $6 \mathrm{~cm}$ depth of irrigation at each interval and pan coefficient was taken 0.75 (by FAO 56).

\section{Comparison of CROPWAT model and climatological method}

After analyzing both methods for irrigation scheduling, it can be seen that through the climatological method of irrigation scheduling, $323.20 \mathrm{~mm}$ of total gross irrigation was required out of which $300 \mathrm{~mm}$ water was given through five irrigations at 22 , 42, 63, 81, and 93 DAS, considering field efficiency. Whereas according to CROPWAT model the irrigation water requirement was $252.2 \mathrm{~mm}$ which was lesser than climatological method and After 36 days from the sowing of mustard, the first irrigation of $58.1 \mathrm{~mm}$ should be given to protect the crop from water stress condition. Further irrigations should be given after 52, 68, and 80 days after sowing with 66.2, 65.9, 65.9, and $63.6 \mathrm{~mm}$ respectively. Yield from CROPWAT irrigation was $1162 \mathrm{~kg} / \mathrm{ha}$ and through climatological method of irrigation scheduling yield was $922 \mathrm{~kg} / \mathrm{ha}$. Comparison of Cropwater requirement for mustard crop from both methods is shown in table 3 and figure 3 .

From Study, it can be concluded that with proper management of water as per crop requirement through CROPWAT model more yield can be obtained than climatological method. So, for better field water use efficiency CROPWAT model irrigation scheduling can be used for mustard in the region.

\section{References}

CROPWAT Models". Published in Agron. J. 92:679-690 pp: 679-689. (2000).

Hossain, M.B, Yesmin, M., and Biswas J.C. 2017 Irrigation scheduling of rice using CROPWAT

Jose cavero, Inmafarre, Philippe Debaeke, and Jose M. Faci., "Simulation of Maize Yield under Water Stress with the EPICphase and

Lal B, Hossain MS, Alam MB, Ripon MA. Effect of irrigation and sowing method on yield and yield attributes of mustard. Rajshahi University journal of life \& earth and agricultural sciences. 2013; 41:65-70. 
Mehanuddin H, Nikhitha G R, Prapthishree K S, Praveen L B, Manasa H.G 2018 Study on Water Requirement of Selected Crops and Irrigation Scheduling Using CROPWAT International Journal of Innovative Research in Science, Engineering and Technology. DOI: 10.15680/IJIRSET. 2018.0704032 2018

Model in the western Region of Bangladesh. The Agriculturist 15(1): 19-27(2017)

Panda BB, Bandyopadhyay SK, Shivay YS. Effect of irrigation level, sowing dates and varieties on yield attributes, yield, consumptive water use and water use efficiency of Indian mustard. Journal of agril. Sci. 2004; 74(6):339-342.

Patel JR. Effect of irrigation and nitrogen on mustard. Journal Maharashtra Agril. Uni. 1999; 23: 259-261(2007)

RathnaRaju., YellaReaddy K., Satyanarayana T.V and Yogitha P. "Estimation of
Crop water requirement using CROPWAT software in Appapuram channel command under Krishna western delta". International jernoul of Agriculture sciences. (2016).

Shah, P.V., Mistry, R.N., Amin, J.B, Parmar, A.M. 2015 Irrigation scheduling using cropwat, (IJAREST), Volume 2, Issue April- 2015.

Shakeel Ahmad Bhat, B. Pundit. J.N. Khan, Kumar and Rehana Jan., "Water Requirements and Irrigation Scheduling of Maize Crop using CROPWAT Model”. pp.: 1662-1670. (2017).

Sherring, A, and Sing, S., 2019 Crop water estimation and irrigation scheduling of mustard crop using CROPWAT 8.0 and AQUACROP 6.1 at Prayagraj region. International Journal of current microbiology and applied science 23(7) 34-38. (2019)

\section{How to cite this article:}

Neel Praveen Kullu, Mintu Job, D. K. Rusia, Pramod Rai and Alpna Dubey. 2019. Comparative Study of Irrigation Scheduling for Mustard Crop using Climatological Method and CROPWAT Model. Int.J.Curr.Microbiol.App.Sci. 8(12): 1575-1582.

doi: https://doi.org/10.20546/ijcmas.2019.812.189 